\title{
Thermal Analysis of a Commercial Plate Fin Heat Exchanger with Non- uniform Inlet Flow Conditions
}

\author{
Sven De Schampheleire, Kathleen De Kerpel, Bernd Ameel, Henk Huisseune, Michel De \\ Paepe
}

Department of Flow, Heat and Combustion Mechanics, Ghent University, Ghent, Belgium

Address correspondence to Sven De Schampheleire, Department of Flow, Heat and Combustion Mechanics, Ghent University, Sint-Pietersnieuwstraat 41, 9000 Ghent, Belgium. E-mail:

Sven.DeSchampheleire@ugent.be.

Phone Number: +32926433 55. Fax Number: +3292643575. 


\begin{abstract}
In studies using computational fluid dynamics software, very often a uniform air stream is applied as inlet boundary condition of a heat exchanger. In actual applications, however, the inlet flow conditions are not uniform. Therefore, the effect of non-uniformities on the thermal performance is characterized in a wind tunnel for a commercially available plate water/air heat exchanger. Three non-uniform flow conditions are investigated. The heat exchanger is $275 \mathrm{~mm}$ wide and $295 \mathrm{~mm}$ high. Three non-uniformities are created by placing a plate $10 \mathrm{~cm}$ upstream of the heat exchanger: the first one covers the right-hand side of the heat exchanger, the second one covers the top half of the heat exchanger and the last obstruction consists of a circular hole of $150 \mathrm{~mm}$ diameter in the middle of a plate. Only the circular obstruction has a significant influence on the heat transfer rate: the external convective resistance is up to $25 \%$ higher compared to the uniform case. The measurement results presented in this study can be used by other researchers to validate numerical simulations with non-uniform inlet conditions.
\end{abstract}




\section{INTRODUCTION}

Current heat exchanger design is based on both numerical and experimental techniques. Due to the decreasing cost of computational power, more and more heat exchangers are (partly) designed using computational fluid dynamics (CFD) [1]. Academic studies based on CFD only cover a small part of the heat exchanger (e.g. one fin row), as the computational efforts to calculate a complete heat exchanger are too high [2]. As a result, complementary experimental work is still necessary. Experimentally, the heat exchanger is typically studied with the Wilson plot technique [3] where it is treated as a 'black box', with two fluid flows entering and exiting the unit.

Manufacturers are continuously searching for more compact heat exchangers units. To achieve this, more advanced fin designs are used, raising the heat transfer surface per unit of volume. In a compact design, the fan is placed as close to the heat exchanger as possible. The positioning of the heat exchanger (in narrow channels or close to a fan unit) results in nonuniform flow conditions at the inlet of the heat exchanger. To compensate for these flow conditions, manufacturers apply safety factors to their design $[4,5]$. If the effect of these nonuniformities can be predicted with more detail, the oversizing can be reduced and the unit can be built more compact.

In order to assess non-uniformities using CFD, heat exchanger models are required since it is not yet computationally tractable to directly calculate an entire heat exchanger. One such model is the 'heat exchanger model' as pre-programmed in CFD software like Fluent (Ansys ${ }^{\circledR}$ ) [6]. First, a heat exchanger is evaluated experimentally at a variety of mass flow rates under uniform conditions. The resulting mass flow rate versus number of transfer units (NTU) curve is then assumed to be valid locally, and used to predict local heat transfer rates corresponding to a 
non-uniform mass flow rate distribution using CFD. However, in order to assess the accuracy of this approach, experimental studies of heat exchanger performance under non-uniform flow conditions are required.

The number of studies on non-uniform inlet airflow (and temperature) distributions are very limited. Fagan [7] studied the effect of a one-dimensional air flow maldistribution on the performance of plate fin condensers and evaporators numerically using an analytical model in 1980. Fagan found capacity decreases up to $20 \%$. Several types of non-uniform flows were studied: linear, parabolic and a 'step' non-uniformity. The largest influence was found for the step non-uniformity. Mueller [8] studied the effect of several patterns of maldistribution on heat exchangers. For turbulent flow, most heat exchangers show only a small reduction in performance. However, for laminar flow the reduction can be quite significant. Beiler and Kröger [9] experimentally investigated the effect of two unmixed fluids on the thermal performance of cross-flow air-cooled heat exchangers. They found a maximum effect on the overall performance of $2 \%$. Rabas [10] numerically studied the effect of non-uniform air inlet flow on the performance of cross flow condensers by analytical modelling. The overall heat transfer coefficient was assumed to be proportional to the Reynolds number to the power 0.6. Both one- and two-dimensional non uniformities were studied. Even for severe non-uniformities, the effectiveness of the heat exchanger decreases with less than 7\%. T'Joen et al. [11] studied different types of non-uniformities (resp. quadratic, linear and cubic air distribution profiles) on a heat exchanger with adapted inclined louvered fins tested in a wind tunnel. They observed a maximum effect on the global heat transfer coefficient $U$ for the quadratic flow profile of $8 \%$ (the relative uncertainty on the data is $6.8 \%$ ). 
In this work, a commercial wavy-fin and flat tube heat exchanger will be studied experimentally for air velocities between $1.7 \mathrm{~m} / \mathrm{s}$ and $7.6 \mathrm{~m} / \mathrm{s}$. The 'black box' method will be used: temperatures and mass flow rates upstream and downstream the heat exchanger both for the waterside and the airside are measured. The thermal performance is measured under uniform flow conditions and these results are compared with three non-uniform flow distributions. As the main focus of this work is on the thermal performance of the heat exchanger no pressure drop measurements across the heat exchanger are performed. The novelty of this work is that the obstructions are placed very close to the heat exchanger itself, in order to mimic real flow obstructions. The results of this work can be used to validate CFD results using a heat exchanger model.

\section{DESCRIPTION OF THE HEAT EXCHANGER}

The studied heat exchanger is shown in Figure 1, where the flow direction inside the channels is also indicated. This is a commercial heat exchanger manufactured by AKG. Hot water enters the collector on the right from below, is pumped through 18 flat tubes and exits the heat exchanger at the top of the collector on the left. Air flows over the fin side of the heat exchanger.

An automatic air vent is installed at the highest point of the heat exchanger to ensure a proper degassing of the water circuit. The heat exchanger has a height $(H)$ of $295 \mathrm{~mm}$, a width (w) of $275 \mathrm{~mm}$ and a flow depth of $62.5 \mathrm{~mm}$. The flat tubes are internally finned with offset strip

fins, while there are wavy fins on the airside. An illustration of the fin types that are used and their dimensions are given in Figure 2. 


\section{TEST RIG}

\section{Air- and waterside}

The experimental set-up consists of an open air wind tunnel and a closed hot water loop (see Figure 3). A centrifugal fan (Ventomatic ${ }^{\circledR}$ - AEC 355) draws air through a calibrated nozzle. The fan is equipped with a variable frequency drive which is PID controlled. To obtain a highly uniform velocity profile, a diffuser section is used, followed by a settling chamber with a flow straightener and a double sinusoidal contraction section. This contraction section is built specifically for the studied heat exchanger $\left(275 \times 295 \mathrm{~mm}^{2}\right)$. Except for this contraction section, the experimental setup is exactly the same as the one used in De Schampheleire et al. [3]. The uniformity of the air velocity at the test section inlet is confirmed for air velocities between 2.4 $\mathrm{m} / \mathrm{s}$ and $9.7 \mathrm{~m} / \mathrm{s}$ with 2D hot-wire measurements. The hot-wire is from Dantec Dynamics ${ }^{\circledR}$ (type 55R54). The uncertainty of this hot-wire measurement is $0.05 \mathrm{~m} / \mathrm{s}$. The anemometer is connected to a robot arm which is controlled by a computer. The robot arm can move in two directions, allowing measurements in the vertical plate of the test section. Airside velocity uniformity

$\left(\frac{v_{\max }-v_{\min }}{v_{\max }+v_{\min }}\right)$ falls within $2.5 \%$, while the turbulent intensity (ratio of the root-mean-square of the turbulent velocity fluctuations and the mean velocity) was always smaller than $2 \%$. For a velocity set point of $2.43 \mathrm{~m} / \mathrm{s}$, the velocity profile is shown in Figure 4(a), while the turbulent intensity is shown in Figure 4(b). According to T'Joen et al. [11], a uniform velocity profile is defined when the value for the airside velocity uniformity is smaller than $11 \%$. 
To provide heating, a closed hot water cycle is used (see Figure 3). The pipeline heater has a maximum power of $9 \mathrm{~kW}(\mathrm{e})$ and is PID controlled. The water pump has a relay control and a motorized three way valve controls the waterside mass flow rate to the heat exchanger. The three way valve is controlled through a voltage signal. The water mass flow rate through the heat exchanger is measured with a Coriolis mass flow meter (PROMASS 80-Endress+Hauser). The dashed rectangular zone in Figure 3 represents the test section and is completely insulated with Eurofloor ${ }^{\circledR}(0.023 \mathrm{~W} / \mathrm{mK})$ to minimize the heat loss to the environment. An illustration of the insulated part of the test rig, with the heat exchanger placed upright, is shown in Figure 5. Again, water flows in from the right hand collector to the left.

The heater is controlled to send a certain amount of power to the water circuit. In steadystate operation conditions, this will result in a steady water inlet temperature. In this study the heater is controlled to an inlet water temperature of $55^{\circ} \mathrm{C}$. Steady-state is defined when the standard deviation of the average inlet water temperature varies less than $0.15^{\circ} \mathrm{C}$ over the last 150 measurements (sample rate $0.33 \mathrm{~Hz}$ ). Tests are performed at atmospheric pressure conditions on airside and at $2.1 p_{a t m}$ on waterside.

For all measurements, the waterside mass flow rate is set to a constant value of $600 \mathrm{~kg} / \mathrm{h}$. For this flow rate the airside thermal resistance is dominant. At the same time the temperature difference on the waterside is acceptable in order to acquire good accuracy. The airside thermal resistance accounts for more than $75 \%$ of the overall thermal resistance. For each air flow conditions (one uniform condition and three non-uniform conditions), the airside mass flow rate is varied between 4 set points by adjusting the frequency controller of the fan. The air velocity at the test section inlet varies between $1.7 \mathrm{~m} / \mathrm{s}$ and $7.6 \mathrm{~m} / \mathrm{s}$. The fixed set points are summarized in Table 1. A range of ambient temperatures is given as the experiments take several days. 
Humidity is not taken into account as no condensation occurs in the heat exchanger. For the last non-uniformity, however, the fan was not powerful enough to reach the highest air velocity target, because the pressure drop over the obstruction plate was too large.

These experiments typically result in a $\dot{Q}_{a v g}=\frac{\dot{Q}_{a i r}+\dot{Q}_{w a t e r}}{2}$, where the difference between $\dot{Q}_{a i r}$ and $\dot{Q}_{w a t e r}$ is as small as possible (according to ANSI/ASHRAE-33 standard [12]: smaller than 5\%). However, for this specific heat exchanger, the measurement of $\dot{Q}_{a i r}$ is rather complex. As illustrated in Figure 2, the exit angle of the air flow at the outlet of the heat exchanger is approximately $16^{\circ}$ (corresponding the exit angle of the wavy fins). This implies large nonuniformities in airside velocity at the outlet of the test section, which makes it difficult to measure an average air outlet temperature. Therefore, the local velocity and temperature are measured at a large number of points over the cross section of the test section exit using a hotwire anemometer. A mass flow average air outlet temperature can then be determined. Next, $\dot{Q}_{\text {air }}$ was calculated and the difference between $\dot{Q}_{a i r}$ and $\dot{Q}_{\text {water }}$ can be determined to verify the heat balance. This was done for one velocity set point and for the uniform case to verify the accuracy of the test rig. The heat balance closes within 3\%, which proves that there are no significant heat losses to the environment. Due to the difficulty of determining the airside heat transfer rate, for the non-uniform flow measurements the heat transfer rate is assumed to be equal to the waterside heat transfer (i.e. there are no heat losses). Five parameters are continuously logged during the measurements, on the water- and on the airside of the heat exchanger: $\dot{m}_{\text {water }}$ (Coriolis mass flow meter PROMASS 80 of Endress+Hauser), $T_{\text {water,in }}$ (2 K-type thermocouples), $T_{\text {water,out }}\left(2 \mathrm{~K}\right.$-type thermocouples), $\dot{m}_{\text {air }}$ (over a calibrated nozzle) and $T_{\text {air,in }}$ (1 K-type thermocouple). 
To operate and log all measurements of the test rig a DAQmx system with LabVIEW ${ }^{\circledR}$ software is used.

\section{Non-uniformities}

The non-uniformities are chosen in such a way that it is possible to (a) use the measurements as a validation for the numerical CFD work and (b) to simulate real obstructions just before the heat exchanger (fans, narrow constraints were the heat exchanger has to be placed in, etc.). This is done by blocking off parts of the test section $10 \mathrm{~cm}$ before the heat exchanger using a Plexiglas ${ }^{\circledR}$ plate with a thickness of $5 \mathrm{~mm}$. The non-uniformities has to be simple for verification with CFD results both for the uniform and non-uniform case. The obstructions are placed very close to the heat exchanger so the complete wind tunnel, including the fan, doesn't have to be implemented in CFD.

For the first non-uniform flow condition (vertical obstruction), the Plexiglas ${ }^{\circledR}$ plate covers exactly the right half of the test section and is placed on the side of the hot water inlet, where the largest thermal effect is expected (see Figure 6). For the second non-uniformity (horizontal obstruction) the upper half of the inlet is blocked. The third and last non-uniformity (circular obstruction) the Plexiglas ${ }^{\circledR}$ plate cover almost the entire heat exchanger, except for a circular hole of $150 \mathrm{~mm}$ diameter in the middle of the test section, which is illustrated in Figure 7. For this obstruction $78.2 \%$ of the flow area is covered (while it is only $50 \%$ for the two other non-uniformities). 


\section{Measurement Accuracy}

The air- and waterside mass flow rates can be measured accurately. The relative uncertainty on $\dot{m}_{\text {air }}$ is $1.5 \%$ or $3.5 \%$, depending on the pressure drop transducer used. The relative uncertainty follows the Deutsches Institut für Normung (DIN) guidelines (ISO 51671:1991 Standard [13]). For this study and the selected mass flow rate, the uncertainty on $\dot{m}_{\text {water }}$ is taken as the quadratic sum of the absolute error $(0.15 \%$ of the measured value) and twice the standard deviation $\left(\sqrt{(0.15 \% \cdot \text { measured value })^{2}+(2 \sigma)^{2}}\right)$.

All water- and airside temperatures are measured with K-type thermocouples (junction diameter of $1 \mathrm{~mm}$ ), which were calibrated for their specific measuring range using a Druck DBC150 temperature calibrator furnace. The reference temperature is measured with a FLUKE1523 temperature meter with an accuracy of $0.068^{\circ} \mathrm{C}$. The uncertainty of the thermocouples is found to be at most $0.15^{\circ} \mathrm{C}$. All thermocouples are placed pointing with their tip against the flow direction. The waterside temperature measurements are done at two locations (to minimize the uncertainty) in a collector just before and after the heat exchanger collectors. The inlet air temperature is measured in the center of the test section and is considered to be uniform over the test section.

For clarity the uncertainty on the parameters which are logged continuously $\left(\dot{m}_{\text {water }}\right.$,

$\left.T_{\text {water, }, \text { }}, T_{\text {water,out }}, \dot{m}_{\text {air }}, T_{\text {air, }, \text { in }}\right)$ together with their derivatives $\left(\dot{Q}_{\text {water }}, E, R_{\text {ext }}, \eta \cdot h_{\text {ext }}\right.$ and $U A$ ) are reported in Table 2.

In order to be able to indicate the quality of the measurements a thorough uncertainty analysis was performed. Standard error propagation rules as described by Moffat [14] were used to determine the total uncertainty (root-sum-square method). The uncertainties on the 
thermodynamic properties were based on open literature recommendations $[15,16]$. In this study all uncertainties are expressed as $95 \%$ confidence intervals $(2 \sigma)$.

\section{DATA REDUCTION AND DETERMINATION OF CONSTANTS}

\section{Data reduction}

$\dot{Q}_{\text {water }}$ is calculated using Eq. (1). As the mean outlet air temperature cannot be measured in a time efficient way, $\dot{Q}_{a i r}$ is assumed to be equal to $\dot{Q}_{w a t e r}$ (neglecting the heat loss through the insulation, which is justified because the heat losses are smaller than $3 \%$ (see higher)). The airside outlet temperature and heat capacity can be determined iteratively from Eq. (2).

$$
\begin{gathered}
\dot{Q}_{\text {water }}=\dot{m}_{\text {water }} \cdot c_{p, \text { water }} \cdot\left(T_{\text {water,in }}-T_{\text {water }, \text { out }}\right) \\
\dot{Q}=\dot{Q}_{\text {avg }}=\dot{Q}_{\text {water }}=\dot{Q}_{\text {air }}=>T_{\text {air,out }}, c_{p, \text { air }} \text { (iteratively) }
\end{gathered}
$$

The Wilson plot technique [3] is used to determine the airside convective heat transfer coefficient based on experimental data. This technique is based on the separation of the thermal resistance into:

a) Convective heat transfer on waterside $\left(R_{\text {in }}\right)$ and on airside $\left(R_{\text {ext }}\right)$

b) Conductive resistance through the aluminium channel walls $\left(R_{\text {cond }}\right)$

c) Fouling resistances $\left(R_{f, \text { in } \& \text { out }}\right)$

$$
R_{\text {overall }}=\frac{1}{U A}=R_{\text {in }}+R_{f, \text { in \& out }}+R_{\text {cond }}+R_{\text {ext }}
$$


In this equation $U$ is the thermal transmittance and $A$ is the heat transferring surface area. Neglecting the fouling resistances and the conductive resistance, this result in the following expression for the thermal overall resistance (Eq. (4)):

$$
R_{\text {overall }}=\frac{1}{U A}=\frac{1}{h_{\text {in }} \cdot A_{\text {in }}}+\frac{1}{\eta \cdot h_{\text {ext }} \cdot A_{\text {ext }}}
$$

One method to determine the overall heat transfer coefficient $(U A)$ is through the effectiveness $-N T U$ method. The cross flow mixed-unmixed equations for the effectiveness are used. The waterside is assumed to be mixed and the airside unmixed [17]. Since there are only 6 fins over the width of the water channel and offset strip fins promote mixing by vortex shedding, the fully mixed flow across the section of the flat tube is a good approximation. As there is only one tube row, the flow should always be mixed according to Shah and Sekulic [17].

$$
\begin{gathered}
C_{\text {air }}=\dot{m}_{\text {air }} \cdot c_{p, \text { air }} \\
C_{\text {water }}=\dot{m}_{\text {water }} \cdot c_{p, \text { water }} \\
C^{*}=\frac{C_{\min }}{C_{\max }} \\
\dot{Q}_{\text {max }}=C_{\min } \cdot\left(T_{\text {water,in }}-T_{\text {air }, \text { in }}\right) \\
\dot{Q}=C_{\text {water }} \cdot\left(T_{\text {water,in }}-T_{\text {water }, \text { out }}\right) \\
E=\frac{\dot{Q}}{\dot{Q}_{\text {max }}}
\end{gathered}
$$

In case of $C_{\text {air }}=C_{\text {min }}$,

$$
N T U=-\ln \left(\frac{\left(C^{*}+\ln \left(1-E \cdot C^{*}\right)\right)}{C^{*}}\right)
$$


In case of $C_{\text {water }}=C_{\text {min }}$,

$$
N T U=-\frac{\ln \left(1+\ln (1-E) \cdot C^{*}\right)}{C^{*}}
$$

Finally:

$$
U A=N T U \cdot C_{\min }
$$

Next, the other parameters from Eq. (4) have to be determined, in order to get an expression for the lumped heat transfer coefficient $\eta \cdot h_{\text {ext }}$ (like done in Ameel et al. [18]).

\section{Determination of $\boldsymbol{h}_{\text {in }}$}

A correlation from literature is applied [19], where an alternative definition for the hydraulic diameter is used (Eq. (14)).

$$
D_{h, w a t e r}=\frac{4 \cdot s H l}{2 \cdot(s l+H l+t H)+t s}=0.00265 \mathrm{~m}
$$

For this equation the dimensions are taken from Figure 2(a) and Figure 8. It is again important to stress that some of the geometric data were provided from the manufacturer, but all lengths are determined by destructive testing of the heat exchanger. The data of the manufacturer does not always fit with the data obtained through destructive testing.

- $s$ : transverse spacing (free flow width) $=(3.75-0.3) / 1000 \mathrm{~m}$

- $H$ : free flow height $=(3-0.3) / 1000 \mathrm{~m}$

- $t$ : fin thickness $=0.3 / 1000 \mathrm{~m}$

- $l$ : fin depth $=1.5 / 1000 \mathrm{~m}$

$$
R e_{D_{h, \text { water }}}=\frac{\rho_{\text {water }} v_{\text {water }} D_{h, \text { water }}}{\mu_{\text {water }}}
$$




$$
v_{\text {water }}=\frac{\dot{m}_{\text {water }}}{\rho_{\text {water }} A_{\text {free flow water }}} \approx 0.0776 \frac{\mathrm{m}}{\mathrm{s}}
$$

The free flow area in Eq. (16) is calculated based on Figure 8. Every fin is $7.5 \mathrm{~mm}$ long, with a height of $3 \mathrm{~mm}$ and a fin thickness of $0.3 \mathrm{~mm}$. The width of the channel on waterside is $62.5 \mathrm{~mm}$. There are two spacers present to hold both plates at an equidistant location; both are 7 mm long (as indicated on Figure 8). The number of unit cells of fins is thus approximately 6.5 $\left(\frac{62.5-2 * 7}{7.5}=6.46\right)$. The free flow area is calculated as one unit cell (indicated by the two rectangles in the middle indicated in grey in Figure 8) and multiplied with the number of fins per channel. Finally, to obtain the total free flow area, this number is multiplied with 18 (number of channels on waterside).

$$
\begin{gathered}
A_{\text {free flow,water }}=[[(3.75-0.3) \cdot(3-0.3)+(3.75-0.3) \cdot(3-0.3)] \cdot 6.5] \cdot 18= \\
2179.71\left[\mathrm{~mm}^{2}\right]
\end{gathered}
$$

Depending on a critical Reynolds number (Eq. (18)), the Colburn $j$-factor is determined through Eq. (19) or Eq. (20) [19].

$$
R e_{D_{h, \text { water }}}^{*}=257\left(\frac{l}{D_{h, \text { water }}}\right)^{1.23}\left(\frac{t}{l}\right)^{0.58} D_{h}\left(t+1.328\left(\frac{R e_{D_{h, \text { water }}}}{l D_{h, \text { water }}}\right)^{-0.5}\right)^{-1}
$$

If $R e_{D_{h, w a t e r}}<R e_{D_{h, w a t e r}}^{*}$

$$
\begin{aligned}
& j=0.6522\left(\operatorname{Re}_{D_{h, \text { water }}}\right)^{-0.5403}(s / H)^{-0.1541}(t / l)^{0.1499}(t / s)^{-0.0678} \\
& \text { If } \operatorname{Re}_{D_{h, \text { water }}} \geq R e_{D_{h, \text { water }}}^{*} \\
& \qquad j=0.2435\left(\operatorname{Re}_{D_{h, \text { water }}}\right)^{-0.4063}(s / H)^{-0.1037}(t / l)^{0.1955}(t / s)^{-0.1733}
\end{aligned}
$$


Finally, the waterside heat transfer coefficient is calculated through Eq. (21) and (22). A relative uncertainty of $30 \%$ is taken on the resulting waterside convection coefficient conservatively.

$$
\begin{gathered}
S t=j / P r_{\text {water }}^{2 / 3} \\
h_{\text {water }}=\frac{S t \cdot R e_{D_{h, \text { water }} \cdot P r_{\text {water }} \cdot k_{\text {water }}}}{D_{h}}
\end{gathered}
$$

\section{Determination of $\boldsymbol{A}_{\text {in }}$}

For the determination of $A_{\text {in }}$, the fins are assumed to have no offset in the direction of the water flow. This simplifies the calculation. As there are 18 water channels present with a flow depth of $275 \mathrm{~mm}$ and on average 6.5 of those fins, $A_{\text {in }}$ is calculated based on the wetted perimeter.

$$
A_{\text {in }}=\text { wetted perimeter } \cdot 0.275 \cdot 18=0.7915 \mathrm{~m}^{2}
$$

The wetted perimeter is calculated based on Figure 8. Again, the calculation is done for one unit cell and multiplied with the number of fins (6.5):

$$
\text { wetted perimeter }=[2 \cdot(3.75-0.3)+2 \cdot(3-0.3)] \cdot 2 \cdot 6.5=0.1599 \mathrm{~m}
$$

The absolute uncertainty on the fin length is $0.5 \mathrm{~mm}$, while the uncertainty on the fin thickness is $0.1 \mathrm{~mm}$, on the number of fins 0.5 and on the flow depth of $1 \mathrm{~mm}$. This results in a relative uncertainty on $A_{\text {in }}$ of $14 \%$.

\section{Determination of $\boldsymbol{A}_{\text {ext }}$}


$A_{\text {ext }}$ is determined as the sum of the base plate area, where the hot water flows, and the fin area (Eq. (25)).

$$
A_{\text {ext }}=A_{\text {base plate }}+A_{\text {fins }}=3.6967 \mathrm{~m}^{2}
$$

As indicated in Figure 9, one wavy fin measures $13 \mathrm{~mm}$ and the flow depth on airside is $62.5 \mathrm{~mm}$. This makes (on average) 4.8 wavy fins (as shown in Figure 9(b)). On the other hand, over the width of the heat exchanger $(275 \mathrm{~mm})$, there are 55 fins (indicated as triangles in Figure $9(\mathrm{a})): \frac{275}{5}=55$. Here the thickness of the fins itself is not taken into account for simplicity. The dimensions listed in Figure 9 correspond with Figure 2(b). The area of the base plate is determined through Eq. (26).

$$
A_{\text {base plate }}=18 \cdot 2 \cdot \frac{(275 \cdot 62.5)}{10^{6}}=0.6188 \mathrm{~m}^{2}
$$

The area of the fins is determined by multiplying:

- Number of channels at airside: 19 (1)

- Number the area of one wavy (dashed on Figure 9(b)): $(11.28 \cdot 6.8 \cdot 2) \cdot 2$, taking into account the two legs of the triangle. (2)

- Number of sides, top and bottom of the fin: 2 (3)

- Number of triangles, as indicated in Figure 8(a): $\frac{275}{5}=55$ (4)

- Number of wavy fins over the airside flow depth: $\frac{62.5}{13}=4.8$ (on average) (5)

$$
A_{\text {fins }}=(1) \cdot(2) \cdot(3) \cdot(4) \cdot(5)=3.078 \mathrm{~m}^{2}
$$


The uncertainty on $A_{\text {ext }}$ is calculated by taking the uncertainty on the number of triangular elements (like in Figure 9(a)) on 1, the uncertainty on length measurements $0.5 \mathrm{~mm}$ and on the number of wavy fins in the airside flow depth direction 0.5 . This results in a relative uncertainty of $16.7 \%$.

\section{RESULTS AND DISCUSSION}

In the results, the effect of the three obstructions on $R_{\text {ext }}, \eta \cdot h_{\text {ext }}, \mathrm{E}$ and UA will be reported and discussed. The relative uncertainty is always the highest for the lowest airside mass flow rate and varies for $\dot{m}_{\text {air }}$ between $1.5 \%$ and $3.5 \%$, for $R_{\text {ext }}$ between $7.9 \%$ and $12.6 \%$, for $\eta \cdot h_{\text {ext }}$ between $13.9 \%$ and $16.9 \%$, for $E$ between $2.4 \%$ and $4.3 \%$ and for $U A$ between $4.3 \%$ and $11 \%$.

\section{Waterside mass flow rate, $U A$ and the heat exchanger's effectiveness $(E)$}

As the inlet air temperatures are determined by the ambient conditions and the different uniformity tests were done on different days, the heat transfer rate (Figure 10) cannot be used to make comparisons. Instead, the overall heat transfer coefficient is compared. The range of ambient temperature is given in Table 1.

The overall heat transfer conductance $(U A)$ is plotted as function of the air mass flow rate in Figure 11. At the lowest airside mass flow rate, the $U A$ for the horizontal and circular obstruction is higher compared to the uniform case. However, there is no statistically significant difference between the results at this lowest velocity. At higher airside mass flow rates, the 
uniform case yields the best performance. At the highest velocity, the horizontal obstruction has a $U A$ which is $1.5 \%$ lower than the uniform case. However, this result, both for the horizontal and vertical obstruction, is also not statistically significant. Furthermore, only the circular obstruction shows a significant variation from the uniform case: a decrease in $U A$ of $27.3 \%$ for the highest tested airside mass flow rate. Note that for this circular obstruction, the pressure drop over the obstruction was too high to reach the highest air velocity set point with the current fan unit. For the lowest air mass flow rate, there is no statistically significant difference in thermal performance between the uniform and the non-uniform cases.

At higher air mass flow rates, the difference in thermal performance based on the overall heat transfer conductance $U A$ between the uniform case and the first two non-uniformities is small: variations are between $1 \%$ and $4 \%$. As half of the test section is covered, the other half experiences an increase in local airside velocity, approximately by a factor 2 (as the obstruction is placed fairly close to the heat exchanger). The local heat transfer coefficient will thus also increase across half of the heat exchanger. However, in the typical empirical correlations for the Nusselt number: $N u=f(\operatorname{Re}, \operatorname{Pr})$, the powers of $\operatorname{Re}$ and $\operatorname{Pr}$ are always much smaller than 1 [20]. This indicates that the heat transfer coefficient does not increase linearly with velocity. Depending on the evolution of the convection coefficient in function of the airside velocity, the obstruction will have a more limited or large effect on the thermal performance. As shown in Figure 12, the heat transfer coefficient is approximately linear with the airside velocity for the first two non-uniformities. This results in a limited effect on the heat transfer $(U A)$.

Out of (non-conclusive) infra-red images it is clear that although 50\% of the flow area is blocked $10 \mathrm{~cm}$ before the heat exchanger, less than $50 \%$ of the heat exchanger surface is blocked in case of the horizontal and vertical obstruction. This is because the streamlines will diverge 
after the obstruction. Of course, this will limit the impact of the obstruction on the thermal performance of the heat exchanger. Together with an increase in local convection coefficients, this explains why the effect on UA is so low. At higher airside mass flow rates however, the waterside temperature drop is $1{ }^{\circ} \mathrm{C}$ lower for the vertical and horizontal obstruction compared to the uniform case. This is explainable from the empirical Nusselt correlation. This is also clear from the heat exchanger effectiveness $E$, which represents the ratio between the actual heat transfer rate and the maximum heat transfer rate. The effectiveness declines as a function of the air mass flow rate, as illustrated in Figure 13. The effectiveness decreases as $\dot{q}_{\text {max }}$ increases more rapidly than $\dot{q}$. As for most data points $C_{\text {min }}=C_{\text {air }}$, the airside mass flow rate increases more than the waterside temperature drop. This is also the case for the uniform case. However, the vertical and horizontal obstruction result in a decrease in effectiveness of only $3 \%$. This is directly due to the higher airside mass flow rate and the smaller available flow area, meaning that there is less time and space to exchange the heat.

The effect of the circular obstruction is more severe. Here the total surface area is lowered by a factor of 4.6. This means that the local airside velocities will be more than tripled, taken into account the divergence effect in the 10 centimeters between the obstruction and the heat exchanger. Again, from the typical powers of $\operatorname{Re}$ and $\operatorname{Pr}$ in the Nusselt correlation [20] it is clear that the thermal performance of the heat exchanger will be penalized more profound as the convection coefficient flattens off for higher mass flow rates, as can be seen in Figure 12. As a result, the $U A$-values are $17.8 \%$ lower compared to the uniform case. As for the second to last airside mass flow rate, the waterside temperature drop is $1^{\circ} \mathrm{C}$ lower compared to the uniform case. This results in an effectiveness drop for the heat exchanger of $4.6 \%$-points, for the highest airside mass flow rate. 
The previous results clearly show that only severe obstructions result in a significant difference in thermal performance. For obstructions that cover only half of the heat exchanger, no significant differences is measured. For severe obstructions (covering over $78 \%$ over the flow area) effects up to $17 \%$ on the thermal conductance are reported. T'Joen et al. [11] obtained a similar but less pronounced result. The linear non-uniform profile, which resembles the vertical obstruction in this work, resulted in overall heat transfer coefficient $U$ of $7.7 \%$. The authors also looked to the water exit temperatures to explain the effects in thermal performance, together with a local velocity and temperature field of the heat exchanger. The influence in thermal performance on the overall heat transfer coefficient is less severe in this case as the velocity profile from the vertical obstruction does not decrease linearly: it remains flat for the first half of the heat exchanger. Other authors however, like Fagan [7] reports effects in thermal performance up to $20 \%$ for a step-like non-uniformity. These authors report an 'intensity of the nonuniformity' expressed as the ratio of the maximum face velocity to the mean face velocity. For the step-like non-uniformity this intensity is $75 \%$. This is very similar to our circular obstruction, explaining the similar effect in thermal performance (20\% versus $17 \%$ in this work).

\section{Airside convective thermal resistance $\left(\boldsymbol{R}_{\text {ext }}\right)$ and lumped heat transfer coefficient $(\boldsymbol{\eta} \cdot \boldsymbol{h})$}

Figure 14 shows that the same trends are observed for the airside convective thermal resistance and the lumped heat transfer coefficient $\left(\eta \cdot h=\frac{1}{R_{\text {ext }} \cdot A_{\text {ext }}}\right.$, see Figure 12). Only for the circular obstruction the thermal resistance and the convection coefficient doesn't resp. decreases or increases with the air mass flow rate as it does for the other non-uniform and uniform cases. For the horizontal and vertical non-uniformity, no significant differences are observed. For both the airside convective resistance and the convection coefficient, the differences are between $1 \%$ 
and 6\%. This is because of the low impact of the non-uniformity. The local airside velocity is be less than doubled, meaning that the impact on the non-linear increase in convection coefficient will be smaller compared to more severe obstructions.

For the circular obstruction at an air mass flow rate of $0.54 \mathrm{~kg} / \mathrm{h}$ the external convective resistance and the lumped convection coefficient differing resp. $25 \%$ and $20 \%$ compared to the uniform case.

\section{CONCLUSIONS}

In this study, the influence of three non-uniform airside distributions is measured experimentally for a commercial plate/fin heat exchanger. The dimensions of the heat exchanger are measured through destructive testing. The uniformity of the wind tunnel is checked with $2 \mathrm{D}$ hot wire measurements. The purpose of this study is the implementation of this case in CFD software. Therefore, all the obstructions are placed $10 \mathrm{~cm}$ before the inlet of the heat exchanger. In this way, not the complete wind tunnel, including the fan, has to be implemented in CFD. Three non-uniformities are studied. Two obstructions are covering 50\% of the total flow area, resp. covering the vertical or horizontal half of the heat exchanger. The most severe obstruction consists of a circular hole and covers $78 \%$ of the total flow area.

The obstructions covering 50\% of the total flow area does not result in a significant thermal effect. This is because of the limited impact of the obstruction. The increase in local airside velocity is modest so the increase in convection coefficient is large enough to hold the 
heat transfer rate on a same level as for the uniform case. Whereas the circular obstruction is causing a significant effect on the thermal performance: the external convective resistance is up to $25 \%$ higher compared to the uniform case.

The experimental results presented in this study can be used to validated numerical simulations of these non-uniformities in CFD.

\section{ACKNOWLEDGEMENT}

The authors want to thank Hugo Bellinck for his technical assistance.

\section{NOMENCLATURE}
A area, $\mathrm{m}^{2}$
$c_{p} \quad$ specific heat capacity, $\mathrm{J} / \mathrm{kgK}$
C heat capacity rate, $\mathrm{W} / \mathrm{K}$
C* heat capacity ratio, dimensionless
$D_{h} \quad$ hydraulic diameter, $m$
E effectiveness, eq. (10), dimensionless
h convection heat transfer, $\mathrm{W} / \mathrm{m}^{2} \mathrm{~K}$
$\mathrm{H}$ height, $\mathrm{m}$
j colburn j-factor, dimensionless
$\mathrm{k}$ conductivity, $\mathrm{W} / \mathrm{mK}$
1 fin depth, $m$
$\dot{m} \quad$ mass flow rate, $\mathrm{kg} / \mathrm{s}$ 


\begin{tabular}{|c|c|}
\hline M & Motor, - \\
\hline $\mathrm{Nu}$ & Nusselt number, dimensionless \\
\hline $\mathrm{p}$ & pressure, $\mathrm{Pa}$ \\
\hline $\operatorname{Pr}$ & Prandtl number, dimensionless \\
\hline$\dot{Q}$ & heat transfer rate, $\mathrm{W}$ \\
\hline $\mathrm{R}$ & thermal resistance, $\mathrm{K} / \mathrm{W}$ \\
\hline $\operatorname{Re}$ & Reynolds number, dimensionless \\
\hline $\operatorname{Re}^{*}$ & critical Reynolds number, dimensionless \\
\hline $\mathrm{s}$ & fin spacing, $m$ \\
\hline St & Stanton number, dimensionless \\
\hline $\mathrm{t}$ & fin thickness, m \\
\hline $\mathrm{T}$ & temperature, $\mathrm{K}$ \\
\hline $\mathrm{U}$ & global heat transfer coefficient, W/m² $\mathrm{K}$ \\
\hline UA & overall heat transfer conductance, W/K \\
\hline $\mathrm{V}$ & velocity, $\mathrm{m} / \mathrm{s}$ \\
\hline $\mathrm{w}$ & width, m \\
\hline$X$ & (view in) $\mathrm{x}$-direction \\
\hline
\end{tabular}

\section{Greek Symbols}

$\Delta \quad$ difference

$\delta \quad$ uncertainty on

$\eta \quad$ fin efficiency, dimensionless

$\rho \quad$ density, $\mathrm{kg} / \mathrm{m}^{3}$ 
$\sigma \quad$ standard deviation, dimensionless

\section{Subscripts}

$\begin{array}{cl}\text { air } & \text { airside } \\ \text { atm } & \text { atmospheric } \\ \text { avg } & \text { average } \\ \text { cond } & \text { conduction } \\ \text { Dh } & \text { the characteristic length is } \mathrm{D}_{\mathrm{h}} \\ \text { ext } & \text { external } \\ \mathrm{f} & \text { fouling } \\ \text { in } & \text { inside } \\ \text { max } & \text { maximum } \\ \text { min } & \text { minimum } \\ \text { out } & \text { outside } \\ \text { water } & \text { waterside }\end{array}$

\section{Acronyms}

A, B, AB Mixing system of three way valve

CFD Computational Fluid Dynamics

HEX Heat exchanger

NTU Number of Transfer Units 


\section{REFERENCES}

[1] Taborek, J., Evolution of heat exchanger design techniques, Heat Transfer Eng., vol. 1, pp. 15-29, 1979.

[2] Ameel, B., Degroote, J., T'Joen, C., De Jaeger, P., Huisseune, H., De Schampheleire, S., Vierendeels, J., De Paepe, M. , Optimization of X-shaped louvered fin and tube heat exchangers while maintaining the physical meaning of the performance evaluation criterion, Appl. Therm. Eng., vol. 58, pp. 136-145, 2013.

[3] De Schampheleire, S., De Jaeger, P., Huisseune, H., Ameel, B., T’Joen, C., De Kerpel, K., De Paepe, M., Thermal hydraulic performance of 10 PPI aluminium foam as alternative for louvered fins in an HVAC heat exchanger, Appl. Therm. Eng., vol. 51, pp. 371-382, 2013.

[4] Hewitt, G.F., S. J. Pugh, Approximate design and costing methods for heat exchangers, Heat Transfer Eng., vol. 28, pp. 76-86, 2007.

[5] Shilling, R. L., Rudy, M.P., Rudy, T.M., Risk-based design margin selection for heat exchangers, Heat Transfer Eng., vol. 32, pp. 307-313, 2011. 
[6] Ansys Fluent 12.0 Theory guide, Chapter 6: Heat Exchangers. April 2009.

[7] Fagan, T., The effect of air flow maldistribution on air-to-refrigerant heat exchanger performance, ASHRAE Trans., DV80-7, pp. 699-713, 1980.

[8] Mueller, A.C., Effects of some types of maldistribution on the performance of heat exchangers, Heat Transfer Eng., vol. 8, pp. 75-86, 1987.

[9] Beiler, M.G., Kröger, D.G., Thermal performance reduction in air-cooled heat exchangers due to non-uniform flow and temperature distributions, Heat Trans. Eng., vol. 17, pp. 82-92, 1996.

[10] Rabas, T.J., Effects of non-uniform inlet flow and temperature distributions on the thermal performance of air-cooled condensers, maldistribution of flow and its effect on heat exchanger performance, Proc. $24^{\text {th }}$ National Heat Transfer Conference and Exhibition, Pittsburgh, Pa., USA, ASME, New York, NY, pp. 29-35, 1987.

[11] T’Joen, C., Willockx A., Steeman H.-J. \& De Paepe M., Performance prediction of compact fin-and tube heat exchangers in maldistributed airflow, Heat Trans. Eng., vol. 28, pp. 986-996, 2007.

[12] Standard 33-2000 (ANSI-ASHRAE33), methods of testing forced circulation air cooling and air heating coils, American society of heating, refrigerating and air-conditioning engineers, Atlanta, Georgia, USA, 2000.

[13] ISO, Measurement of fluid flow by means of pressure differential devices - Part 1: Orifices plates, nozzles and venture tubes inserted in circular cross-section conduits running full (ISO 5167-1:1991) (September 1995). Geneva, Switzerland.

[14] Moffat, R.J., Describing the uncertainties in experimental results, Exp. Therm. Fluid Sci., vol. 17 , pp. 3-17, 1988. 
[15] Kadoya, K., Matsunaga, N., Nagashima, A., Viscosity and thermal conductivity of dry air in the gaseous phase, J. Phys. Chem. Ref. Data, vol. 14, pp. 947-970, 1985.

[16] Wagner, W., Prub, A., The IAPWS formulation 1995 for the thermodynamic properties of ordinary water substance for general and scientific use, J. Phys. Chem. Ref. Data, vol. 31, pp. $387-535,2002$.

[17] Shah, R.K., Sekulic, D.P., Fundamentals of Heat Exchanger Design, Hoboken, New Jersey, John Wiley \& Sons, 2003.

[18] Ameel, B., Degroote, J., T’Joen, C., Huisseune, H., De Schampheleire, S., Vierendeels, J., De Paepe, M., Accounting for the effect of the heat exchanger length in the performance evaluation of compact fin and tube heat exchangers, Appl. Therm. Eng., vol. 65, pp. 544-553, 2014.

[19] Teruel, M.H., Nakaskima, C.Y., Paglione, P., "Rectangular offset strip-fin heat exchanger lumped parameters dynamic model," Prod. of $3^{\text {rd }}$ CTA-DLR Workshop on data analysis \& Fight control, S.J. Campos, Brazil, (2009). Online available on: http://www.ctadlr2009.ita.br/Proceedings/PDF/59420.pdf (last accessed: 6/10/2014).

[20] Kakac, S., Liu, H., Pramuanjaroenkij, A., Heat exchangers: selection, rating, and thermal design, Third edition, CRC Press, Taylor \& Francis Group, U.S.A., 2012. 
Table 1 Fixed set point for the tests

\begin{tabular}{|c|c|c|c|c|}
\hline $\begin{array}{c}\boldsymbol{T}_{\text {air }, \text { in }}\left[{ }^{\circ} \boldsymbol{C}\right] \\
\text { (range) }\end{array}$ & $\boldsymbol{T}_{\text {water, } \text { in }}\left[{ }^{\circ} \mathrm{C}\right]$ & $\dot{\boldsymbol{m}}_{\text {water }}[\mathrm{kg} / \mathrm{h}]$ & $\dot{\boldsymbol{m}}_{\text {air }}[\mathrm{kg} / \mathbf{s}]$ & $\boldsymbol{v}_{\text {air }}[\mathrm{m} / \mathbf{s}]$ \\
\hline $23.6-25.2$ & 55 & 600 & 0.159 & 1.7 \\
\hline $24-26$ & 55 & 600 & 0.346 & 3.7 \\
\hline $25.6-28$ & 55 & 600 & 0.535 & 5.7 \\
\hline $22.2-23.9$ & 55 & 600 & 0.719 & 7.6 \\
\hline
\end{tabular}


Table 2 Uncertainty on continuous logged parameters

\begin{tabular}{|c|c|}
\hline \multicolumn{2}{|c|}{ Uncertainty on... } \\
\hline$\delta T$ & $0.15^{\circ} \mathrm{C}$ \\
\hline$\delta \dot{m}_{\text {water }}$ & $0.15 \%$ (PROMASS 80-Endress+Hauser) \\
\hline$\delta \Delta p$ & $0.2 \%$ (Halstrup-Walcher PU 0 - 250Pa) \\
& $1 \%$ (Halstrup-Walcher PU 0 - 2500Pa) \\
\hline$\delta m_{\text {air }}$ & $1.5 \%-3.5 \%$ (depending on used pressure \\
& transducer) \\
\hline$\delta Q_{\text {water }}$ & $1.9 \%-3.4 \%$ \\
\hline$\delta E$ & $2.4 \%-4.3 \%$ \\
\hline$\delta R_{\text {ext }}$ & $7.9 \%-12.6 \%$ \\
\hline
\end{tabular}




\begin{tabular}{|c|c|}
\hline$\delta \eta \cdot h_{\text {ext }}$ & $13.9 \%-16.9 \%$ \\
\hline$\delta U A$ & $4.3 \%-11 \%$ \\
\hline
\end{tabular}

\section{List of Figure Captions}

Figure 1 Picture of the studied commercial fin-and-plate heat exchanger

Figure 2 waterside (a) and airside (b) fin dimensions of the studied heat exchanger (dimensions in $\mathrm{mm}$ )

Figure 3 Experimental air- and waterside test setup

Figure 4 Velocity profile (a) and profile of the turbulent intensities (b) for a velocity setpoint of $2.43 \mathrm{~m} / \mathrm{s}$ measured by a 2D hotwire anemometer

Figure 5 Illustration of the insulated part of the test rig

Figure 6 Illustration of the vertical obstruction 
Figure 7 Illustration of the circular obstruction

Figure 8 Schematic illustration of the simplifications to calculate $A_{\text {flow }}$ (Figure not to scaleonly one unit cell drawn - dimensions are in $\mathrm{mm}$ )

Figure 9 Illustration of the simplifications to determine $A_{\text {ext }}$. (a) front view, (b) top view (Figure not to scale, dimensions in $\mathrm{mm}$ ).

Figure 10 Waterside heat transfer rate $\left(\dot{Q}_{\text {water }}\right)$ in function of the airside mass flow rate for all studied flow conditions.

Figure 11 The overall heat transfer coefficient $(U A)$ in function of the airside mass flow rate for all studied flow conditions

Figure 12 The lumped convection coefficient $(\eta \cdot h)$ in function of the airside mass flow rate for all studied flow conditions.

Figure 13 The effectiveness $(E)$ in function of the airside mass flow rate for all studied flow conditions.

Figure 14 The external convective resistance $\left(R_{\text {ext }}\right)$ in function of the airside mass flow rate for all studied flow conditions. 


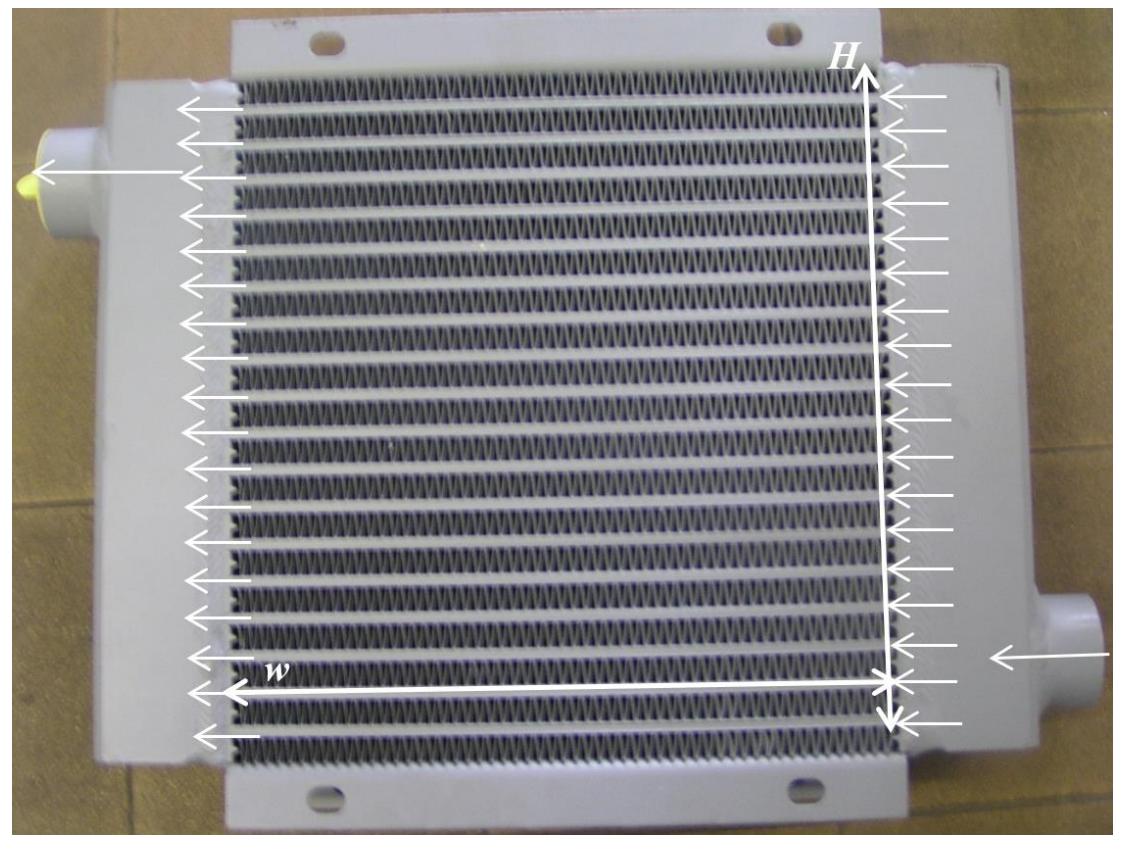

Figure 1 Picture of the studied commercial fin-and-plate heat exchanger 
(a)

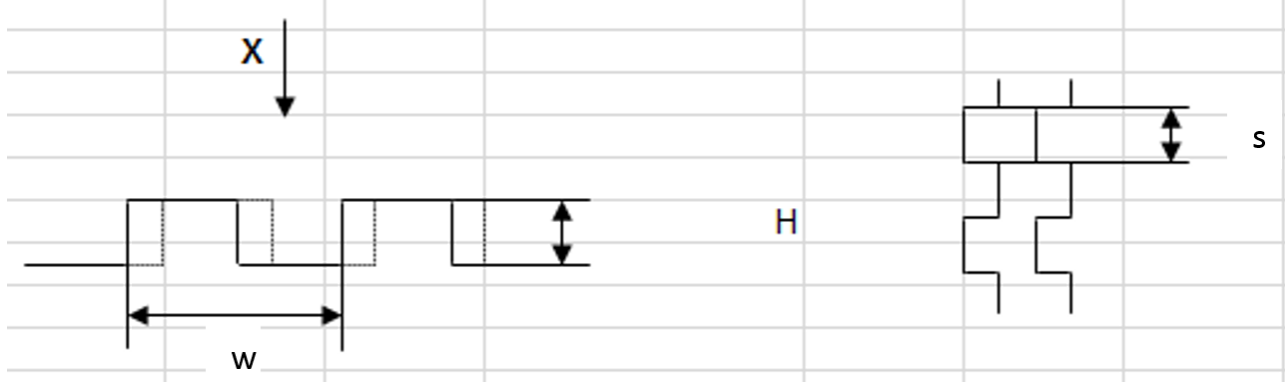

\begin{tabular}{cccc}
\hline w & H & S & t \\
\hline 7.5 & 3 & 1.5 & 0.3 \\
\hline
\end{tabular}

(b)

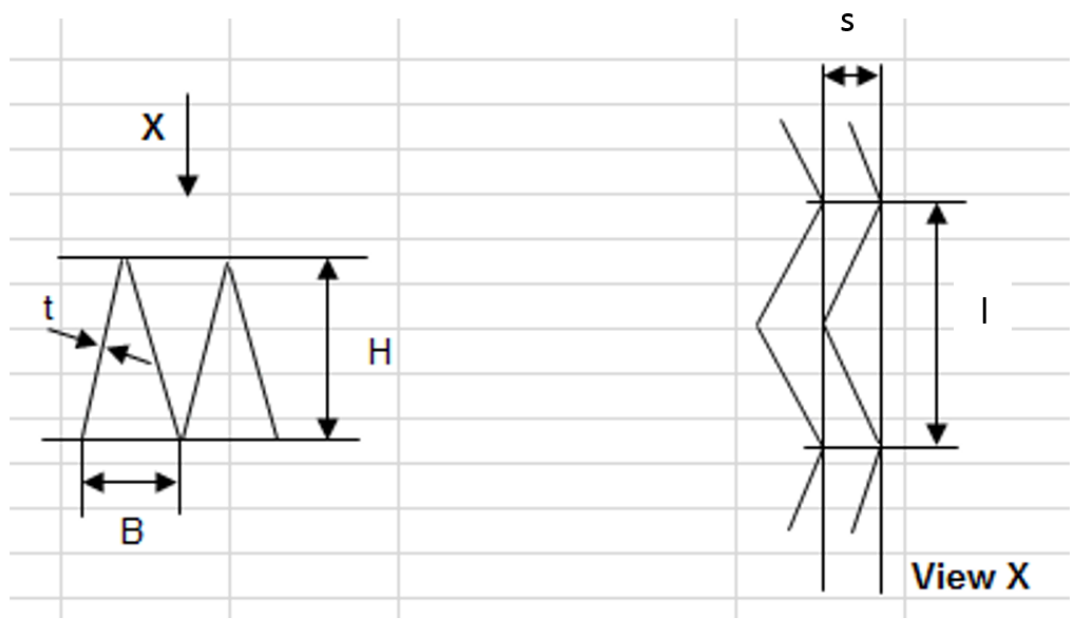

\begin{tabular}{ccccc} 
w & H & l & S & t \\
\hline 5 & 11 & 13 & 2 & 0.2
\end{tabular}

Figure 2 waterside (a) and airside (b) fin dimensions of the studied heat exchanger (dimensions in mm) 


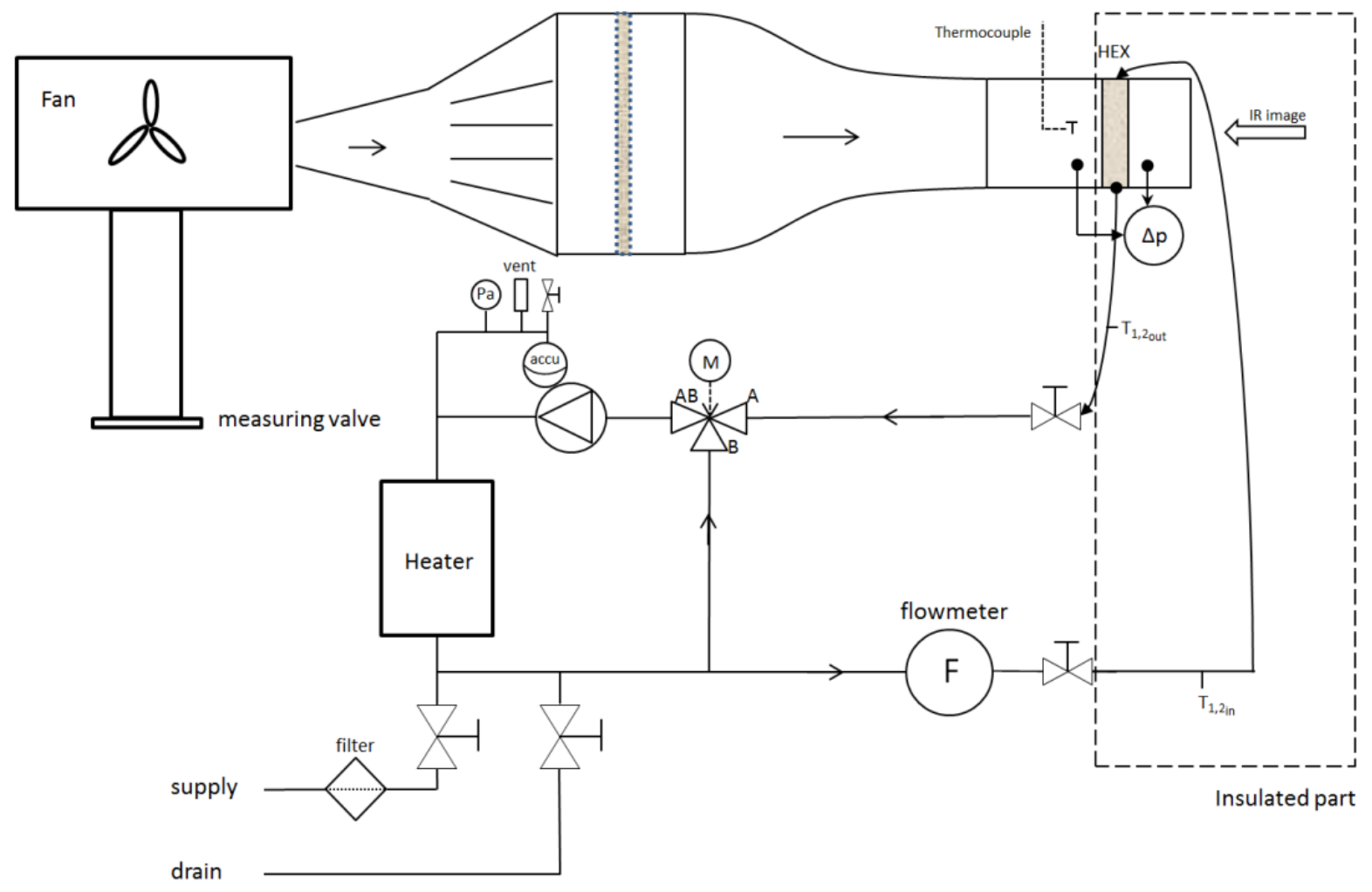

Figure 3 Experimental air- and waterside test setup 

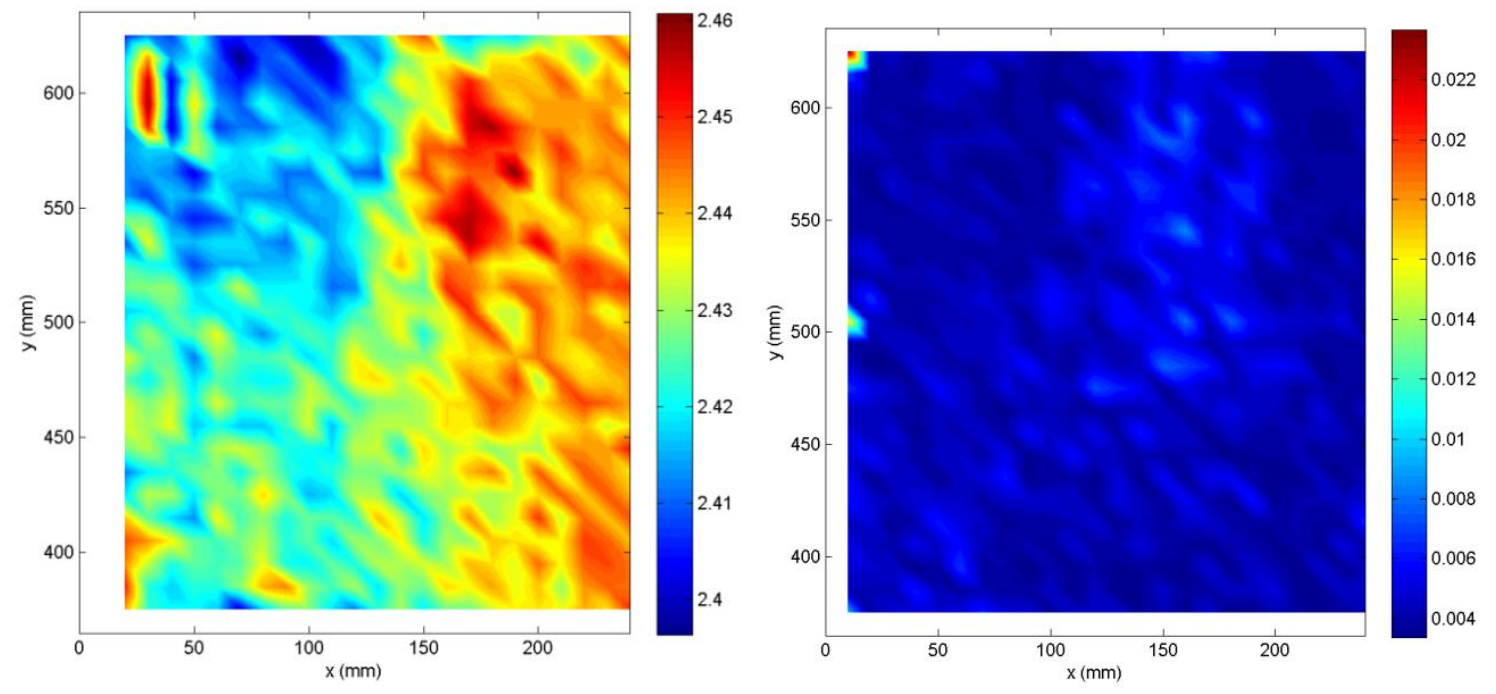

Figure 4 Velocity profile (a) in $\mathrm{m} / \mathrm{s}$ and profile of the turbulent intensities (b), dimensionless, for a velocity setpoint of the fan of $2.43 \mathrm{~m} / \mathrm{s}$ measured by a $2 \mathrm{D}$ hotwire anemometer 

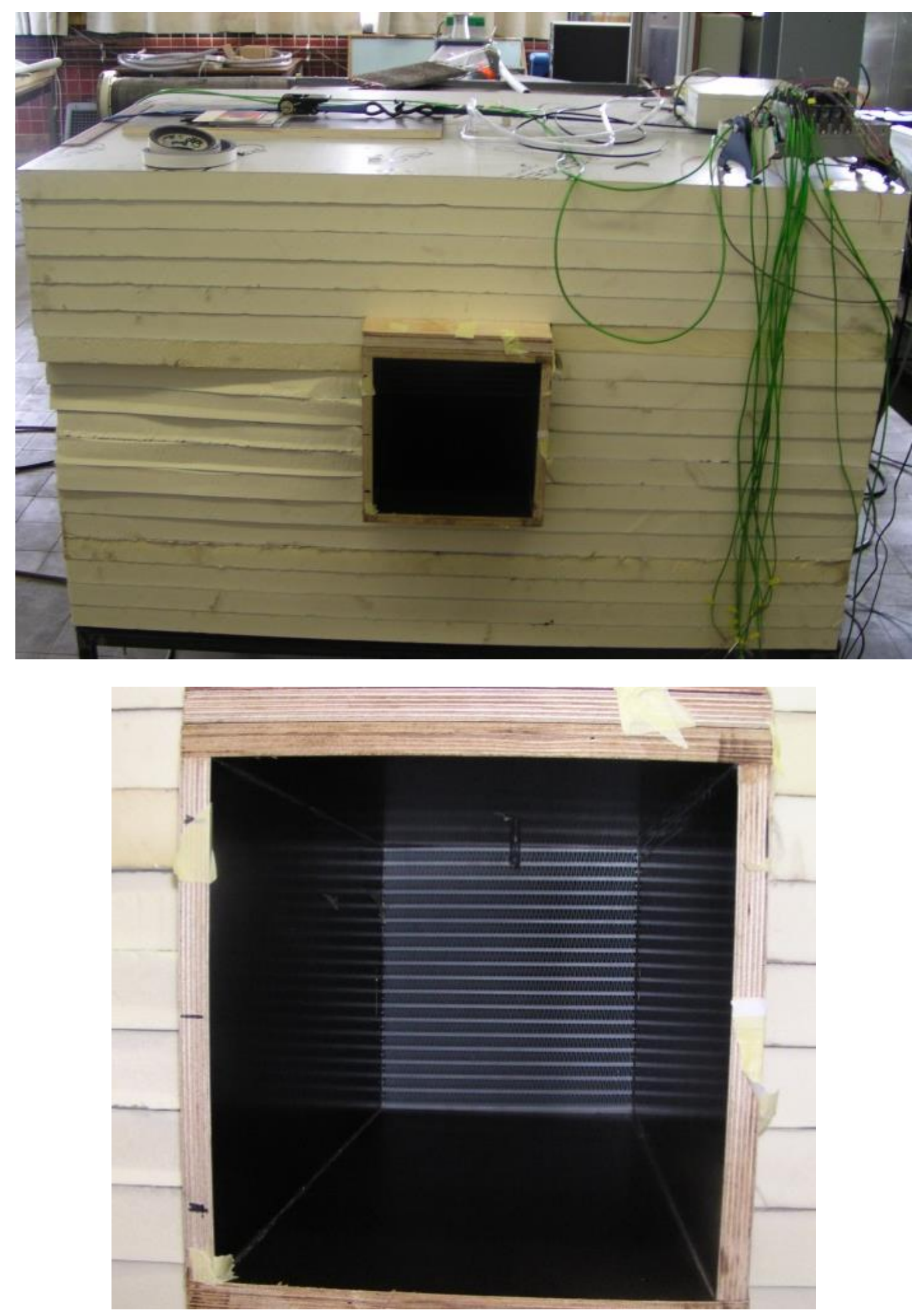

Figure 5 Illustration of the insulated part of the test rig 


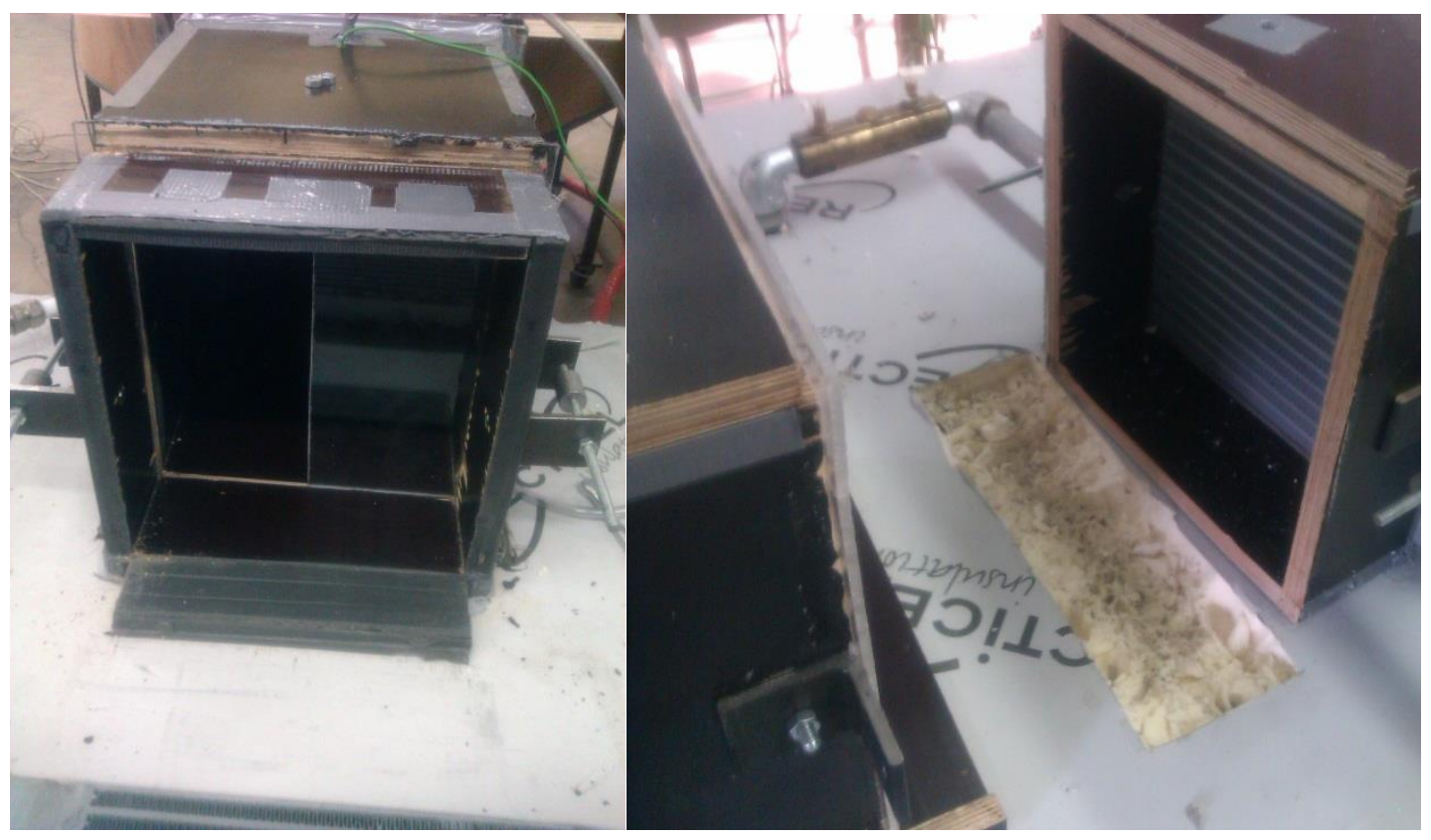

Figure 6 Illustration of the vertical obstruction. 


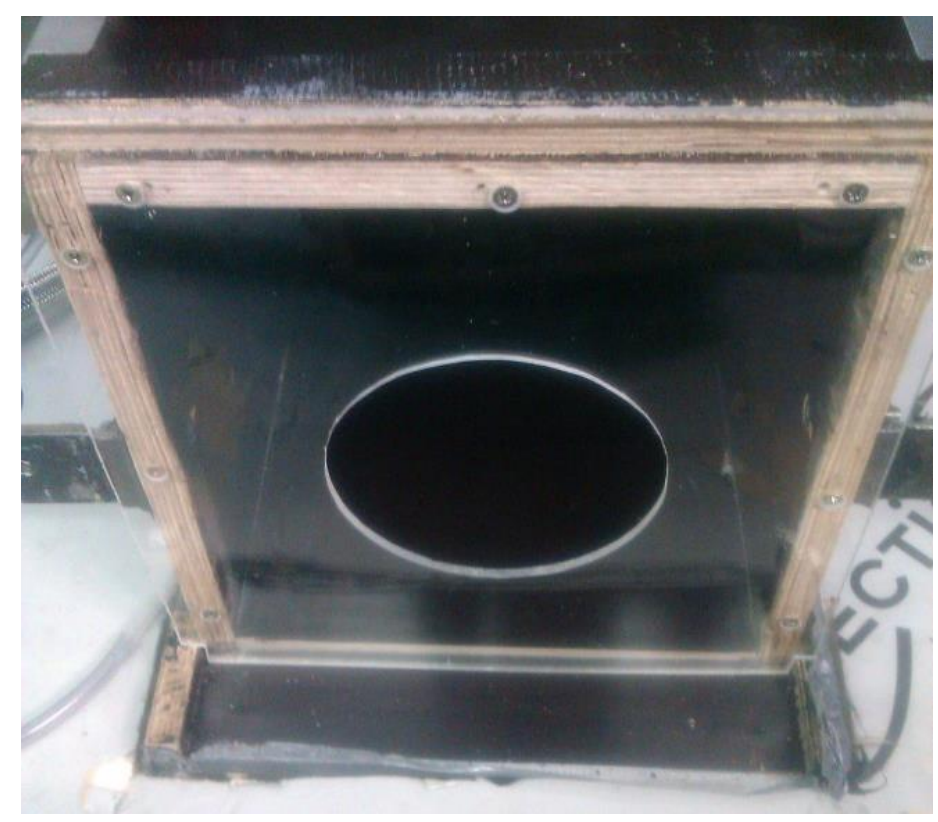

Figure 7 Illustration of the circular obstruction. 


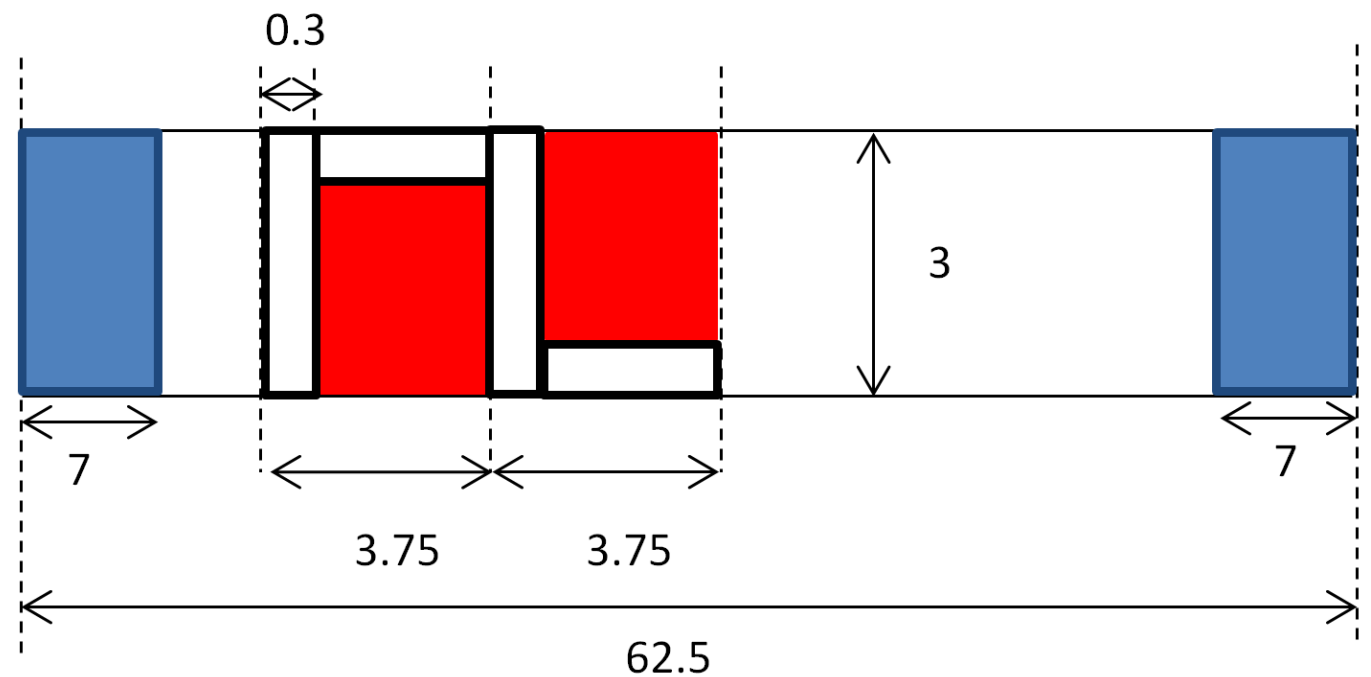

Figure 8 Schematic illustration of the simplifications to calculate $\boldsymbol{A}_{\text {flow }}$

(Figure not to scale - only one unit cell drawn - dimensions are in mm) 


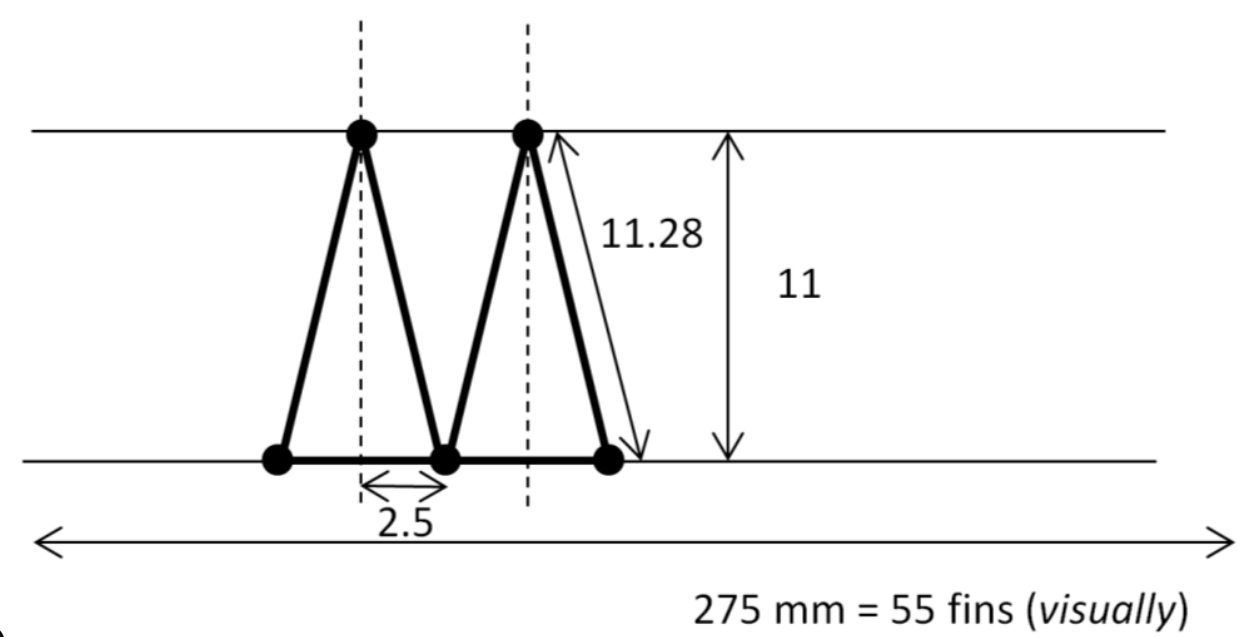

(a)

$$
275 \mathrm{~mm}=55 \text { fins (visually) }
$$

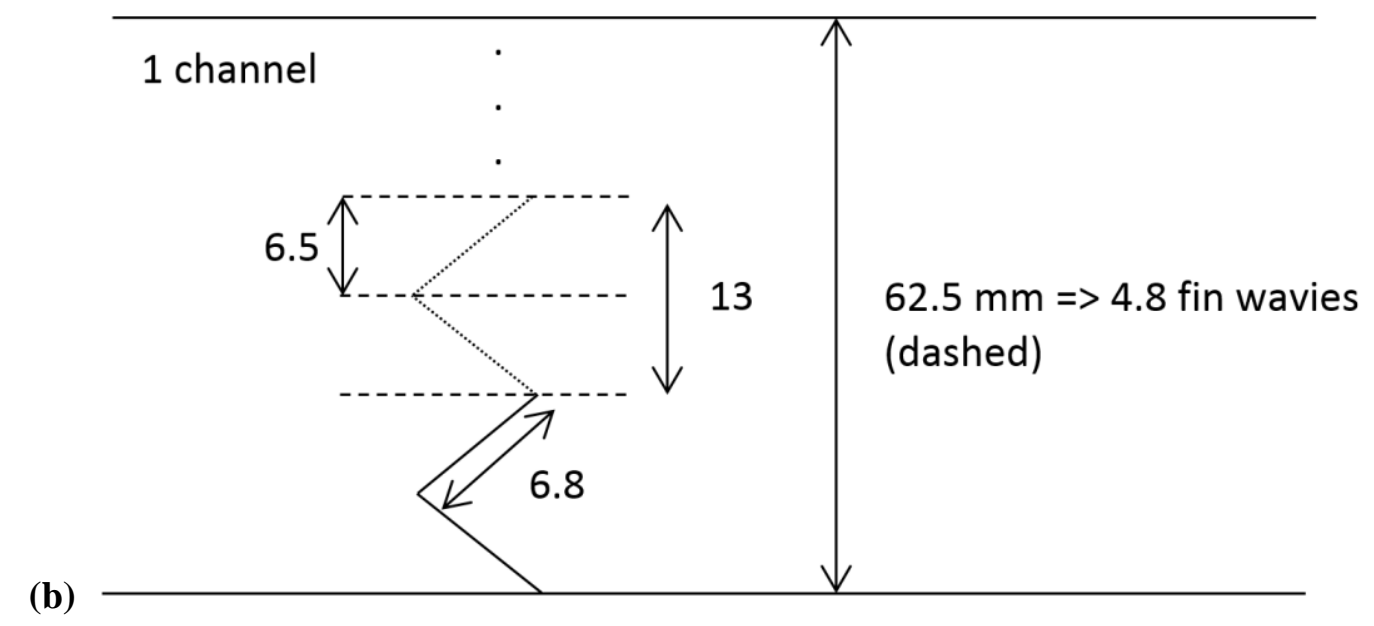

Figure 9 Illustration of the simplifications to determine $A_{\text {ext }}$ (a) front view, (b) top view (Figure not to scale, dimensions in $\mathrm{mm}$ ). 


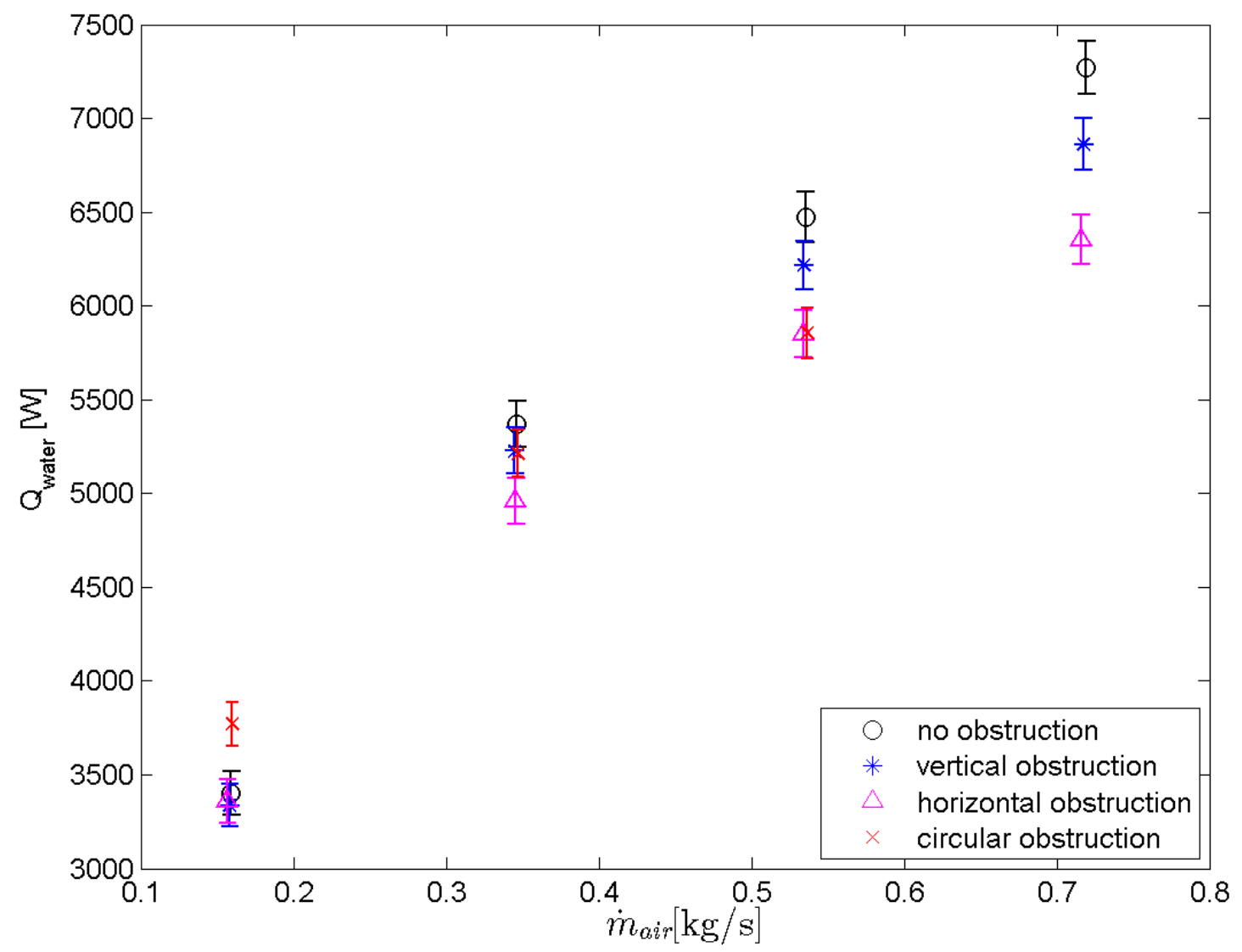

Figure 10 Waterside heat transfer rate $\left(\dot{Q}_{\text {water }}\right)$ in function of the airside mass flow rate for all studied flow conditions. 


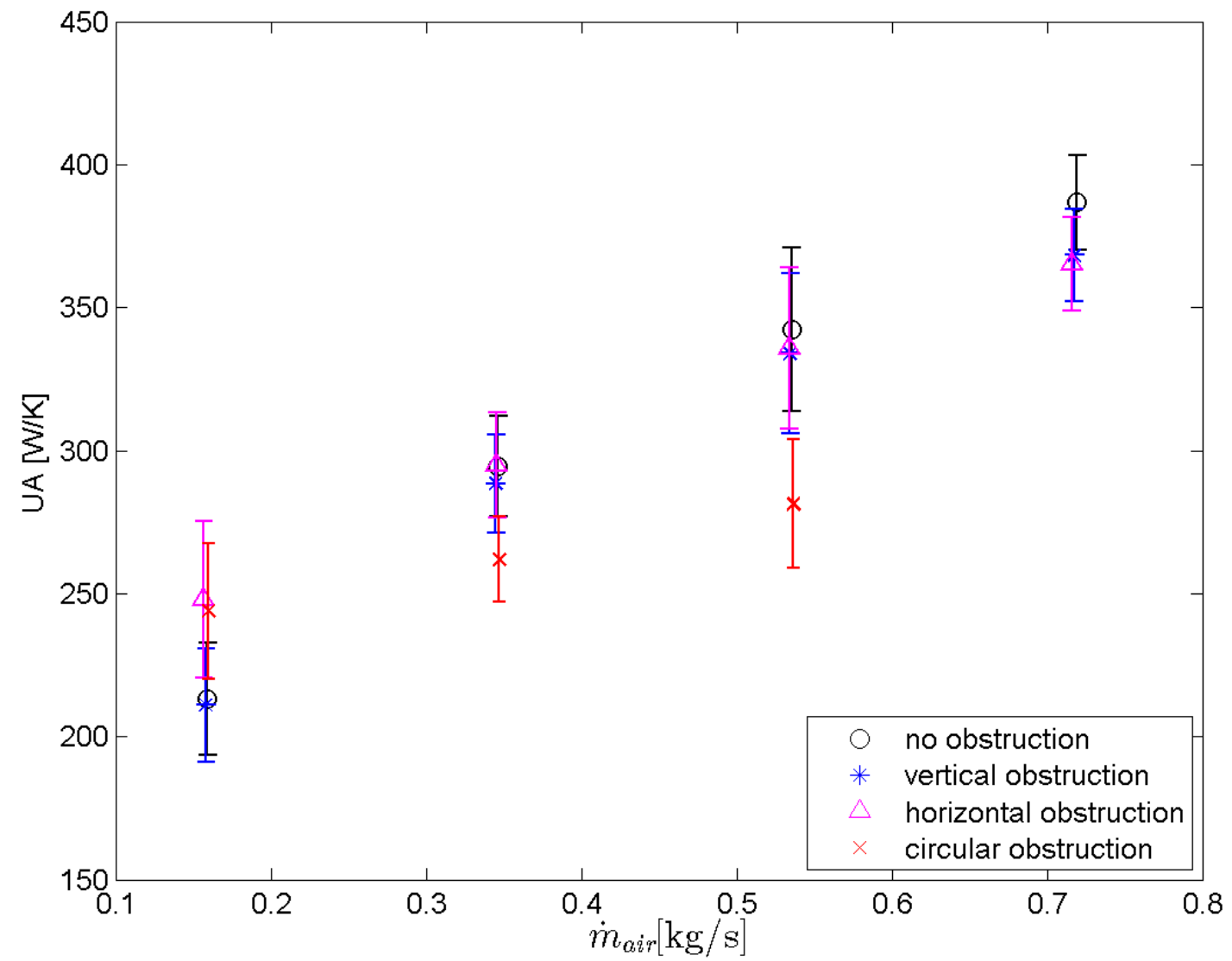

Figure 11 The overall heat transfer coefficient $(U A)$ in function of the airside mass flow rate for all studied flow conditions. 


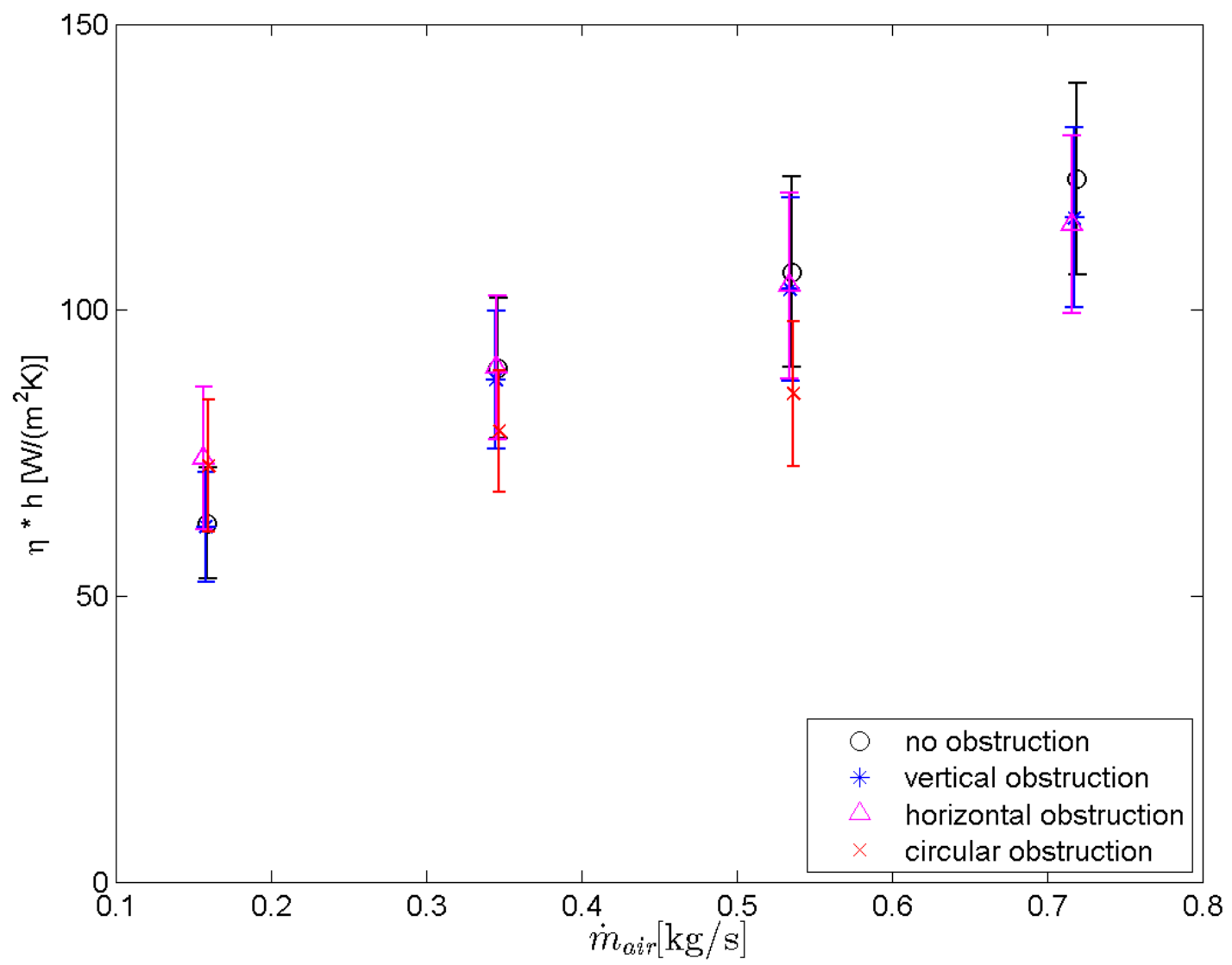

Figure 12 The lumped convection coefficient $(\eta \cdot h)$ in function of the airside mass flow rate for all studied flow conditions. 


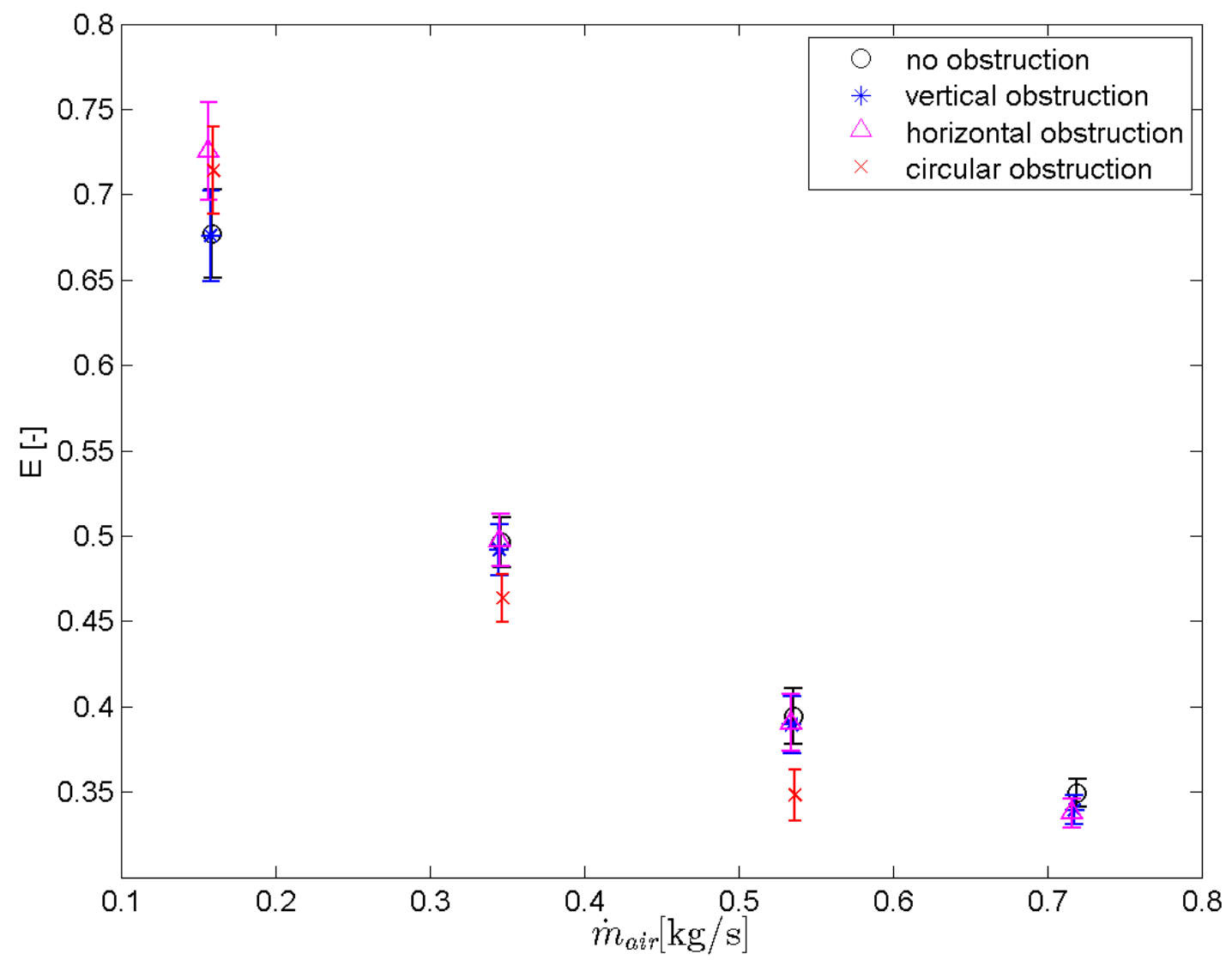

Figure 13 The effectiveness $(E)$ in function of the airside mass flow rate for all studied flow conditions. 


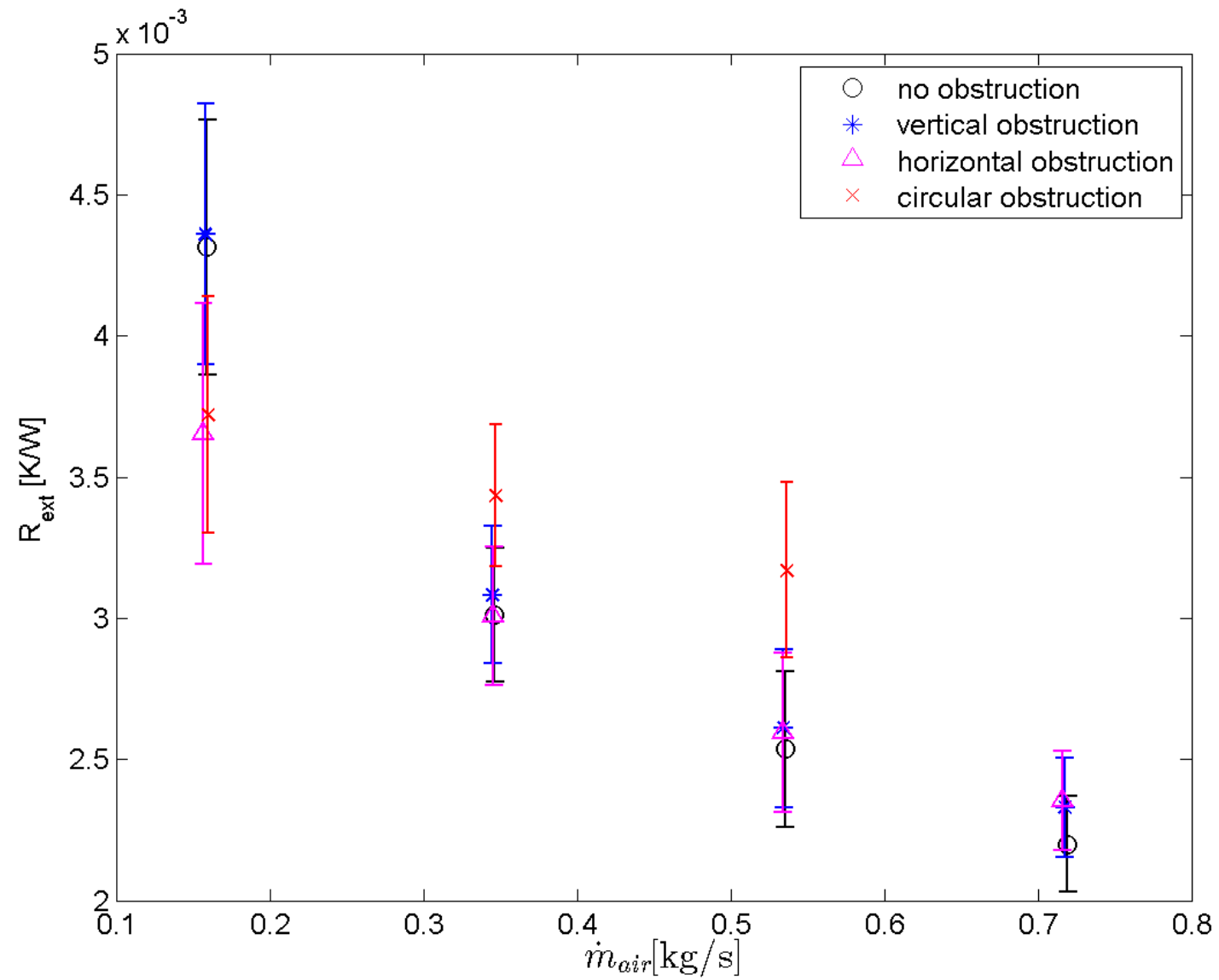

Figure 14 The external convective resistance $\left(R_{\text {ext }}\right)$ in function of the airside mass flow rate for all studied flow conditions. 


\section{BIBLIOGRAPIC INFORMATION}

\begin{tabular}{|c|c|}
\hline & $\begin{array}{l}\text { Sven De Schampheleire is a Ph.D. student at the Department of Flow, } \\
\text { Heat and Combustion Mechanics, Ghent University, Belgium. He } \\
\text { received his master's degree in electromechanical engineering from Ghent } \\
\text { University in 2011. His master's dissertation investigates the thermo- } \\
\text { hydraulic aspects of metal foam as alternative for louvered fins in heat } \\
\text { exchangers and was honored with the 'Atlas Copco Airpower' price } \\
\text { 2011. Current research interest in the numerical modeling of natural } \\
\text { convection in open-cell metal foam using CFD. }\end{array}$ \\
\hline & $\begin{array}{l}\text { Kathleen De Kerpel is a postdoctoral researcher at the Department of } \\
\text { Flow, Heat and Combustion Mechanics, Ghent University, Belgium. She } \\
\text { received her master's degree in electromechanical engineering from } \\
\text { Ghent University in } 2010 \text {. Her main research interest is two-phase } \\
\text { refrigerant flow in compact fin and tube heat exchangers. }\end{array}$ \\
\hline & $\begin{array}{l}\text { Bernd Ameel is a postdoctoral researcher at the Department of Flow, } \\
\text { Heat and Combustion Mechanics, Ghent University, Belgium. He } \\
\text { received his Ph.D. from Ghent University in } 2014 \text { and his master's degree } \\
\text { in electromechanical engineering from the same university in } 2010 \text {. His } \\
\text { main research interest is the optimization of compact fin and tube heat } \\
\text { exchangers. }\end{array}$ \\
\hline & $\begin{array}{l}\left.\text { Henk Huisseune ( }{ }^{\circ} 1984\right) \text { is a postdoctoral researcher at the Department of } \\
\text { Flow, Heat and Combustion Mechanics, Ghent University, Belgium. He } \\
\text { obtained his Ph.D. from Ghent University in } 2011 \text { and his master's } \\
\text { degree in electromechanical engineering from the same university in } \\
\text { 2007. For his master's thesis, he was honoured with the 'Umicore Prize } \\
\text { for Graduate Dissertations'. During his doctoral period, he studied the } \\
\text { flow, heat transfer and pressure drop in compact heat exchangers using a } \\
\text { combined experimental and numerical approach. His current research }\end{array}$ \\
\hline
\end{tabular}




\begin{tabular}{|l|l|}
\hline $\begin{array}{l}\text { interests are design and optimization of heat exchangers and heat sinks, } \\
\text { heat pumps, organic Rankine cycles, thermal energy storage and energy } \\
\text { efficiency of systems. He is (co-)author of } 29 \text { articles published in } \\
\text { international peer reviewed journals and } 51 \text { conference papers. }\end{array}$ \\
$\begin{array}{l}\left.\text { Michel De Paepe ( }{ }^{\circ} 1972\right) \text { is professor of Thermodynamics in the Faculty } \\
\text { of Engineering at Ghent University. He graduated as Master of Science in } \\
\text { Electro-Mechanical Engineering at the Ghent University in 1995. In 1999 } \\
\text { he obtained the Ph.D. in Electro-Mechanical Engineering at the Gent } \\
\text { University, graduating on 'Steam Injected Gas Turbines with water } \\
\text { Recovery'. He is currently heading the Research Group Applied } \\
\text { Thermodynamics and Heat Transfer at the Faculty of Engineering at the } \\
\text { Ghent University. Research focuses on: thermodynamics of new energy } \\
\text { systems, performance of HVAC systems and energy in buildings and } \\
\text { complex heat transfer phenomena in industrial applications, as in compact } \\
\text { heat exchangers, refrigerant two-phase flow and electronics cooling. } \\
\text { Michel De Paepe is (co-)author of more than } 80 \text { papers published in } \\
\text { international peer reviewed journals and more than 250 conference } \\
\text { papers. For his master thesis and his Ph.D. he received the WEL price } \\
\text { Energy. }\end{array}$ \\
\hline
\end{tabular}

